\title{
Plasma osteopontin concentrations in preeclampsia - is there an association with endothelial injury?
}

\author{
Balázs Stenczer ${ }^{1}$, János Rigó Jr¹, Zoltán \\ Prohászka $^{2,3}$, Zoltán Derzsy ${ }^{1}$, Levente Lázár ${ }^{1}$, \\ Veronika Makó ${ }^{2}$, László Cervenak ${ }^{3}$, Krisztián \\ Balogh ${ }^{4}$, Miklós Mézes ${ }^{5}$, István Karádi² and Attila \\ Molvarec $^{1, *}$ \\ ${ }^{1}$ First Department of Obstetrics and Gynecology, \\ Semmelweis University, Budapest, Hungary \\ 2 Third Department of Internal Medicine, Semmelweis \\ University, Budapest, Hungary \\ ${ }^{3}$ Research Group of Inflammation Biology and \\ Immunogenomics, Hungarian Academy of Sciences, \\ Budapest, Hungary \\ ${ }^{4}$ Research Group of Animal Breeding and Hygiene, \\ Faculty of Animal Science, University of Kaposvár, \\ Kaposvár, Hungary \\ ${ }^{5}$ Department of Nutrition, Faculty of Agricultural and \\ Environmental Sciences, Szent István University, Gödölló, \\ Hungary
}

\begin{abstract}
Background: It has been previously reported that plasma osteopontin (OPN) concentrations are increased in cardiovascular disorders. The goal of the present study was to determine plasma OPN concentrations in healthy pregnant women and preeclamptic patients, and to investigate their relationship to the clinical characteristics of the study subjects and to markers of inflammation [C-reactive protein (CRP)], endothelial activation [von Willebrand factor antigen (VWF:Ag)] or endothelial injury (fibronectin), oxidative stress [malondialdehyde (MDA)] and trophoblast debris (cellfree fetal DNA).

Methods: Forty-four patients with preeclampsia and 44 healthy pregnant women matched for age and gestational age were involved in this case-control study. Plasma OPN concentrations were measured with ELISA. Serum CRP concentrations were determined with an autoanalyzer using the manufacturer's reagents. Plasma VWF:Ag was quantified by ELISA, while plasma fibronectin concentrations were measured by nephelometry. Plasma MDA concentrations were estimated by the thiobarbituric acid-based colorimetric assay. The amount of cell-free fetal DNA in maternal plasma was determined by quantitative real-time PCR analysis of the sexdetermining region $\mathrm{Y}(S R Y)$ gene. For statistical analyses, non-parametric methods were applied.
\end{abstract}

\footnotetext{
*Corresponding author: Attila Molvarec, MD, PhD, Hangya lépcsó 9, Budapest, 1121, Hungary

Phone: +3620957 1636, Fax: +3613176174,

E-mail: molvarec@ freemail.hu

Received August 2, 2009; accepted October 13, 2009;

previously published online November 30, 2009
}

\begin{abstract}
Results: Serum levels of CRP, as well as plasma concentrations of VWF:Ag, fibronectin, MDA and cell-free fetal DNA were significantly higher in preeclamptic patients than in healthy pregnant women. There was no significant difference in plasma OPN concentrations between controls and the preeclamptic group. However, preeclamptic patients with plasma fibronectin concentrations in the upper quartile had significantly higher plasma OPN concentrations than those below the 75th percentile, as well as healthy pregnant women [median (interquartile range): 9.38 (8.10-11.99) vs. 7.54 (6.31-9.40) and $7.40(6.51-8.80) \mathrm{ng} / \mathrm{mL}$, respectively, $\mathrm{p}<0.05$ for both]. Furthermore, in preeclamptic patients, plasma OPN concentrations showed a significant positive linear association with plasma fibronectin (Spearman $\mathrm{R}=0.38$, standardized regression coefficient $(\beta)=0.41$, $\mathrm{p}<0.05$ for both).

Conclusions: Plasma OPN concentrations are increased in preeclamptic patients with extensive endothelial injury. However, further studies are warranted to explore the relationship between OPN and endothelial damage.

Clin Chem Lab Med 2010;48:181-7.
\end{abstract}

Keywords: endothelial injury; fibronectin; osteopontin; preeclampsia; pregnancy.

\section{Introduction}

Preeclampsia is a severe complication of human pregnancy with a worldwide incidence of $2 \%-10 \%$ (1). It is one of the leading causes of maternal, as well as perinatal morbidity and mortality, even in developed countries. Despite intensive research efforts, the etiology and pathogenesis of preeclampsia are not completely understood. Increasing evidence suggests that an excessive maternal systemic inflammatory response to pregnancy with systemic oxidative stress and resultant endothelial damage plays a crucial role in the pathogenesis of the disease $(2,3)$. The development of preeclampsia is influenced by both genetic and environmental risk factors, suggesting a multifactorial inheritance (4-9).

Osteopontin (OPN) is a $70-\mathrm{kDa}$ glycoprotein which was demonstrated to be present in the endometrium (10), where it is indicative of a decidualization-like process during pregnancy. It is involved in adhesion and signal transduction at the uterine-placental interface (11). OPN has also been found in the trophoblast of the human placenta, and it can enhance the invasiveness of trophoblast cells in vitro (12). Furthermore, OPN is expressed by endothelial, vascular smooth muscle cells (VSMCs) and immune cells $(13,14)$, and it acts as a proinflammatory Th1 type cytokine (15). The role of 
OPN is considered in several physiological and pathological states, such as embryo implantation, placentation, chronic inflammation and autoimmune diseases $(11,16-20)$.

Local overexpression and elevated plasma concentrations of OPN were observed in aortic, coronary and carotid atherosclerosis (21-24). It was shown that OPN is a component of atherosclerotic plaques and mediates arterial neointima formation as well as dystrophic calcification in the vessel walls (25). These indicate the significance of OPN in the maintenance of chronic inflammation and in plaque formation in atherosclerosis. Interestingly, atherosclerosis shares many risk factors (obesity, dyslipidemia, insulin resistance) and pathogenetic features (inflammation, oxidative stress and endothelial injury) with preeclampsia. In addition, women who develop preeclampsia are at an increased risk of atherosclerotic cardiovascular disorders later in life (26).

In the present study, we measured plasma OPN concentrations in healthy pregnant women and patients with preeclampsia. Given that plasma OPN has recently been observed to be increased in atherosclerotic cardiovascular disorders and that atherosclerosis shares many common pathophysiological mechanisms with preeclampsia, including inflammation and oxidative stress in which OPN has been implicated, we hypothesized that plasma OPN concentrations are increased in preeclampsia. To our knowledge, this is the first report on plasma OPN concentrations in preeclampsia.

We determined several markers of processes involved in the pathogenesis of preeclampsia, such as C-reactive protein (CRP), von Willebrand factor antigen (VWF:Ag), fibronectin, malondialdehyde (MDA) and cell-free fetal DNA. Increased CRP concentrations represent systemic inflammation characteristic of preeclampsia $(27,28)$. Plasma VWF:Ag concentrations indicate endothelial activation (29), while plasma fibronectin concentration is a reliable marker of endothelial injury in preeclampsia (30-33). The latter was shown to reflect the severity, organ involvement and complications of the disorder $(34,35)$. Additionally, fibronectin was found to predict the development of preeclampsia both in normotensive and in hypertensive pregnant women $(34,36,37)$. Plasma concentrations of MDA also were demonstrated to be increased in preeclampsia as a consequence of placental and systemic oxidative stress $(33,38-40)$. Trophoblast particles can frequently be detected in the maternal peripheral circulation in preeclampsia. The mass of this trophoblast debris can be estimated by measurement of copies of cell-free fetal DNA in the maternal blood. Significant increases were observed in preeclampsia compared to normal pregnancies before and after the onset of clinical symptoms (41-44). We also examined whether these laboratory markers, as well as the clinical features of the study subjects, were related to OPN concentrations in our study groups.

\section{Materials and methods}

\section{Study participants}

Our study was designed using a case-control approach. Forty-four preeclamptic patients (19 with severe disease) and 44 normotensive (blood pressure $<140 \mathrm{~mm} \mathrm{Hg}$ systolic and $<90 \mathrm{~mm} \mathrm{Hg}$ diastolic), healthy pregnant women with uncomplicated pregnancies matched for age and gestational age were involved in the study. The sample size provided sufficient statistical power ( $>80 \%$ at a Type I error rate of 0.05 ) to detect differences in plasma OPN concentrations between cases and controls which have been observed previously in coronary artery disease (CAD) (22). The study participants were enrolled in the First Department of Obstetrics and Gynecology and in the Department of Obstetrics and Gynecology of Kútvölgyi Clinical Center, at the Semmelweis University, Budapest, Hungary. All women were Caucasian and resided in the same geographic area in Hungary. Exclusion criteria were multifetal gestation, chronic hypertension, diabetes mellitus, autoimmune disease, angiopathy, renal disorder, maternal or fetal infection and fetal congenital anomaly. The women were fasting, none were in active labor, and none had rupture of membranes.

Preeclampsia was defined as increased blood pressure $(\geq 140$ $\mathrm{mm} \mathrm{Hg}$ systolic or $\geq 90 \mathrm{~mm} \mathrm{Hg}$ diastolic on $\geq 2$ occasions at least $6 \mathrm{~h}$ apart) that occurred after 20 weeks of gestation in a woman with previously normal blood pressure, accompanied by proteinuria $(\geq 0.3 \mathrm{~g} / 24 \mathrm{~h})$. Blood pressure returned to normal by 12 weeks postpartum in each study patient with preeclampsia. Preeclampsia was regarded as severe if any of the following criteria was present: blood pressure $\geq 160 \mathrm{~mm} \mathrm{Hg}$ systolic or $\geq 110 \mathrm{~mm} \mathrm{Hg}$ diastolic, or proteinuria $\geq 5 \mathrm{~g} / 24 \mathrm{~h}$. Pregnant women with HELLP syndrome (hemolysis, elevated liver enzymes, and low platelet count) were not enrolled in this study. Fetal growth restriction was diagnosed if the fetal birth weight was below the 10th percentile for gestational age and gender, based on Hungarian birth weight percentiles (45).

The study protocol was approved by the Regional and Institutional Committee of Science and Research Ethics of the Semmelweis University, and written informed consent was obtained from each patient. The study was conducted in accordance with the Declaration of Helsinki.

\section{Biological samples}

Maternal blood samples were obtained from the antecubital vein into plain tubes, EDTA or sodium citrate, and then centrifuged at room temperature with a relative centrifugal force of $3000 \mathrm{~g}$ for $10 \mathrm{~min}$. The aliquots of serum and plasma were stored at $-80^{\circ} \mathrm{C}$ until the analyses. To determine OPN, fibronectin, MDA and cellfree fetal DNA concentrations, we used EDTA-anticoagulated plasma samples, while VWF:Ag was measured in citrated plasma.

\section{Laboratory methods}

Quantitative detection of plasma OPN was performed using the Human Osteopontin ELISA assay (DRG International, Inc., Mountainside, NJ, USA, Cat. No. EIA-3116) according to the manufacturer's protocol. The sensitivity of the assay was $0.11 \mathrm{ng} / \mathrm{mL}$, and the intra-/inter-assay coefficient of variation $(\mathrm{CV})$ was $<5 \%$ / $<10 \%$, respectively. Serum CRP concentrations were determined using the Cobas Integra 800 (Roche, Mannheim, Germany) and the manufacturer's kits. The lower detection limit was $0.07 \mathrm{mg} / \mathrm{L}$. Plasma VWF:Ag concentrations were quantified using ELISA (Dakopatts, Glostrup, Denmark), while plasma fibronectin concentrations were measured by nephelometry (Dade Behring, Marburg, Germany) according to the manufacturer's instructions. The sensitivities of these assays were $6.16 \%$ and $0.01 \mathrm{~g} / \mathrm{L}$, respectively.

Concentrations of thiobarbituric acid reactive substances in blood plasma were estimated according to the method of Placer et al. (46). The assay procedure was based on the addition of 2-thiobarbituric 
acid with MDA as the end-product of lipid peroxidation, under acidic conditions $(\mathrm{pH}=2.0)$ and high temperature $\left(100^{\circ} \mathrm{C}\right)$. The assay was calibrated using 1,1,3,3-tetraethoxy-propane (Fluka, Buchs, Switzerland) as a source of MDA. Concentrations of blood plasma MDA were calculated as $\mathrm{nmol} / \mathrm{mL}$ of plasma. The limit of quantification was $0.82 \mathrm{nmol} / \mathrm{mL}$.

The amount of cell-free fetal DNA in maternal plasma was determined in patients with male newborns by quantitative real-time PCR analysis of the sex determining region Y $(S R Y)$ gene, as we described previously (47). Briefly, DNA was extracted from $400 \mu \mathrm{L}$ EDTA anticoagulated plasma with the High Pure PCR Template Preparation Kit (Roche Diagnostics, Mannheim, Germany) according to the manufacturer's protocol. The DNA was eluted in $50 \mu \mathrm{L}$ of elution buffer solution, and $1 \mu \mathrm{L}$ was used as a template for the PCR reaction. For the SYBR Green real-time PCR analysis, we used a LightCycler 1.0 System (Roche Diagnostics, Mannheim, Germany). Circulating male fetal DNA was detected with the following primers for the SRY gene: forward 5'-GGC AAC GTC CAG GAT AGA GTG A-3', reverse 5'-TGC TGA TCT CTG AGT TTC GCA TT-3'. The PCR analysis was performed in $10 \mu \mathrm{L}$ reaction volumes containing $1 \mu \mathrm{L}$ DNA, $2.5 \mathrm{pmol} / \mathrm{L}$ of each amplification primer, $1 \mu \mathrm{L}$ of DNA Master SYBR Green I mix (LightCycler FastStart DNA Master SYBR Green I kit: Taq polymerase, dNTP, $\mathrm{MgCl}_{2}$ ), and $6 \mu \mathrm{L}$ of nuclease free water. The PCR was performed in 40 cycles under the following conditions: initial denaturation $8 \mathrm{~min}$ at $95^{\circ} \mathrm{C}, 5 \mathrm{~s}$ denaturation at $95^{\circ} \mathrm{C}, 10 \mathrm{~s}$ annealing at $60^{\circ} \mathrm{C}, 15 \mathrm{~s}$ extension at $72^{\circ} \mathrm{C}$, cooling to $4^{\circ} \mathrm{C}$. To determine the number of copies of circulating DNA present in the plasma sample, a standard dilution curve with a known concentration of male genomic DNA was used. All samples were analyzed in duplicate and scored in blinded fashion. The detection limit was $1.5 \mathrm{pg} / \mathrm{L}$.

\section{Statistical analysis}

Normal distribution of continuous variables was assessed using the Shapiro-Wilk's W-test. As the continuous variables were not normally distributed, non-parametric statistical methods were used. To compare continuous variables between two groups, the Mann-Whitney U-test was applied. Fisher's exact and Pearson's $\chi^{2}$-tests were performed to compare categorical variables between groups. The Spearman rank order correlation was performed to calculate correlation coefficients. As plasma OPN concentrations showed a skewed distribution, multiple linear regression analysis was performed and the scatterplot was created with logarithmically transformed data.
Statistical analyses were carried out using the following software: STATISTICA (version 8.0; StatSoft, Inc., Tulsa, OK, USA) and Statistical Package for the Social Sciences (version 15.0 for Windows; SPSS, Inc., Chicago, IL, USA). For all statistical analyses, $\mathrm{p}<0.05$ was considered statistically significant.

Data are reported as median (interquartile range) for continuous variables and as number (percent) for categorical variables.

\section{Results}

\section{Patient characteristics}

The clinical characteristics of the study participants are described in Table 1 . There were no statistically significant differences in terms of maternal age and gestational age at blood collection and the percentage of smokers and primiparas between the two study groups. The body mass index (BMI) and systolic and diastolic blood pressures were significantly higher, while the gestational age at delivery and the fetal birth weight were significantly lower in the preeclamptic group compared with the control group. Fetal growth restriction was absent in control subjects, whereas the frequency of this condition was $25.0 \%$ in the preeclamptic group.

\section{Laboratory parameters}

As shown in Table 2, serum concentrations of CRP as well as of plasma concentrations of VWF antigen, fibronectin, MDA and cell-free fetal DNA were significantly higher in patients with preeclampsia compared with normotensive, healthy pregnant women. However, there was no significant difference in plasma OPN concentrations between the control and the preeclamptic group (Table 2).

We investigated whether clinical characteristics and laboratory parameters of the study participants were related to plasma OPN concentrations by calculating the Spearman rank order correlation coefficients (continuous variables) or by the Mann-Whitney U-test (categorical variables). As shown in Figure 1, in preeclamptic patients, plasma OPN

Table 1 Clinical characteristics of normotensive, healthy pregnant women and patients with preeclampsia.

\begin{tabular}{llll}
\hline & Controls $(\mathrm{n}=44)$ & $\begin{array}{l}\text { Preeclampsia } \\
(\mathrm{n}=44)\end{array}$ & $\begin{array}{l}\text { Statistical } \\
\text { significance } \\
(\mathrm{p} \text {-value) }\end{array}$ \\
\hline Age, years & & $29(26-32.5)$ & $\mathrm{NS}$ \\
BMI at blood draw, $\mathrm{kg} / \mathrm{m}^{2}$ & $30.5(28-32.5)$ & $29.9(25.7-34.0)$ & $<0.05$ \\
Smokers & $26.1(24.3-28.2)$ & $3(6.8 \%)$ & $\mathrm{NS}$ \\
Primiparas & $0(0 \%)$ & $28(63.6 \%)$ & $\mathrm{NS}$ \\
Systolic blood pressure, mm Hg & $27(61.4 \%)$ & $169.5(160-180)$ & $<0.001$ \\
Diastolic blood pressure, mm Hg & $112.5(110-120)$ & $100(100-110)$ & $<0.001$ \\
Gestational age at blood draw, weeks & $70(60-80)$ & $37(35.5-38)$ & $\mathrm{NS}$ \\
Gestational age at delivery, weeks & $36(36-37)$ & $38(36-38)$ & $<0.001$ \\
Fetal birth weight, g & $39(38-40)$ & $2900(225-3350)$ & $<0.001$ \\
Fetal growth restriction & $3450(3025-3550)$ & $11(25.0 \%)$ & $<0.001$ \\
\hline
\end{tabular}

Data are presented as median (25th-75th percentile) for continuous variables and as number (\%) for categorical variables. NS, not significant; BMI, body mass index. 
Table 2 Laboratory parameters of normotensive, healthy pregnant women and patients with preeclampsia.

\begin{tabular}{llll}
\hline & Controls $(\mathrm{n}=44)$ & Preeclampsia $(\mathrm{n}=44)$ & $\begin{array}{l}\text { Statistical } \\
\text { significance } \\
(\mathrm{p} \text {-value) }\end{array}$ \\
\hline Serum CRP, $\mathrm{mg} / \mathrm{L}$ & & & $<0.05$ \\
Plasma VWF:Ag, $\%$ & $3.59(1.68-7.40)$ & $6.11(1.92-12.12)$ & $<0.05$ \\
Plasma fibronectin, g/L & $148.4(106.6-199.0)$ & $183.0(128.7-242.8)$ & $<0.001$ \\
Plasma malondialdehyde, $\mathrm{nmol} / \mathrm{mL}$ & $0.36(0.32-0.47)$ & $0.58(0.39-0.82)$ & $<.05$ \\
Plasma fetal DNA, $\mathrm{pg} / \mu \mathrm{L}$ & $13.13(8.38-18.61)$ & $0.065(0.034-0.267)$ & $<0.05$ \\
Plasma osteopontin, $\mathrm{ng} / \mathrm{mL}$ & $0.005(0.0-0.178)$ & $7.77(6.60-9.67)$ & $\mathrm{NS}$ \\
\hline
\end{tabular}

Data are presented as median (25th-75th percentile). NS, not significant; CRP, C-reactive protein; VWF:Ag, von Willebrand factor antigen.



Figure 1 Scatterplot with linear fit and regression line of logarithmically transformed values of plasma osteopontin vs. plasma fibronectin concentrations in preeclamptic patients (Spearman $\mathrm{R}=0.38$, standardized regression coefficient $(\beta)=0.41, \mathrm{p}<0.05$ for both).

showed a significant positive linear association with plasma fibronectin concentrations (Spearman $\mathrm{R}=0.38, \mathrm{p}<0.05$ ), even after adjustment for BMI in multiple linear regression analysis (standardized regression coefficient $(\beta)=0.41$, $\mathrm{p}<0.05)$. However, no other relationship was found between clinical features and the measured laboratory parameters (serum CRP, plasma VWF:Ag, MDA and cell-free fetal DNA) of the study subjects and plasma OPN concentrations in normotensive, healthy pregnant women, or in preeclamptic patients (data not shown).

Given the association between plasma OPN and fibronectin concentrations in preeclampsia, we divided our preeclamptic group on the basis of plasma fibronectin concentrations. Preeclamptic patients with plasma fibronectin in the upper quartile ( $\geq 0.82 \mathrm{~g} / \mathrm{L}$ ) had significantly higher plasma OPN concentrations than those below the 75th percentile $(<0.82 \mathrm{~g} / \mathrm{L})$, as well as healthy pregnant women [median (interquartile range): 9.38 (8.10-11.99) vs. 7.54 (6.31-9.40) and $7.40(6.51-8.80) \mathrm{ng} / \mathrm{mL}$, respectively, $\mathrm{p}<0.05$ for both; Figure 2]. This subgroup of patients with preeclampsia was also characterized by more frequent occurrence of the severe form of the disease [ 9 of $13(69.2 \%)$ vs. 10 of 31 (32.3\%),

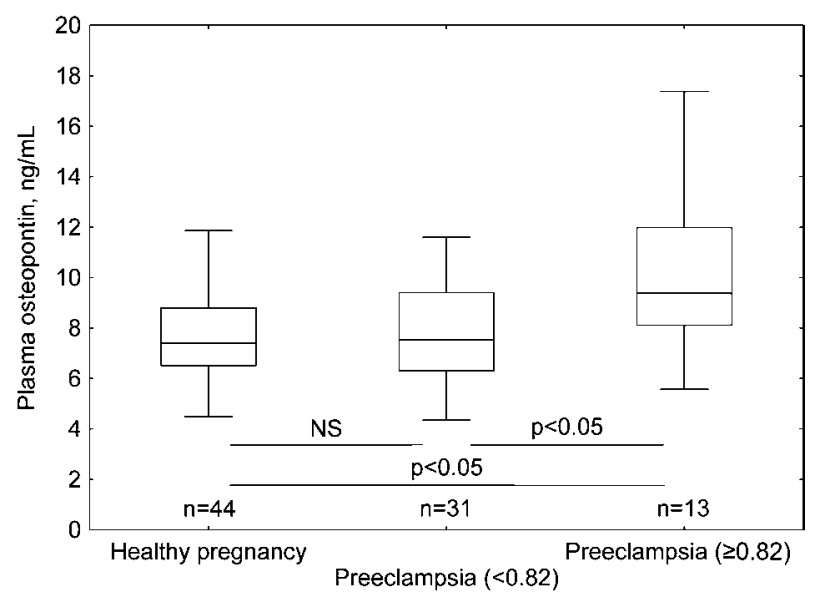

Figure 2 Plasma osteopontin concentrations in preeclamptic patients with plasma fibronectin in the upper quartile $(\geq 0.82 \mathrm{~g} / \mathrm{L}$, $\mathrm{n}=13)$, below the 75 th percentile $(<0.82 \mathrm{~g} / \mathrm{L}, \mathrm{n}=31)$ and in healthy pregnant women $(n=44)$.

Middle line: median; box: interquartile range; Whisker: range (excluding outliers); NS, not significant.

$\mathrm{p}<0.05$ ], as well as by significantly higher diastolic blood pressure [median (interquartile range): 110 (100-120) vs. $100(98-110) \mathrm{mm} \mathrm{Hg}, \mathrm{p}<0.05]$, as compared to preeclamptic women with fibronectin concentrations in the lower three quartiles.

\section{Discussion}

In this study, we found that preeclamptic patients with extensive endothelial injury had significantly higher plasma OPN concentrations compared to those without extensive injury as well as healthy pregnant women. In addition, plasma OPN showed a significant positive linear association with plasma fibronectin concentrations in preeclampsia.

Several clinical surveys reported an association between altered OPN concentrations and cardiovascular diseases. Ohmori et al. observed that OPN plasma concentrations correlate with the extent of CAD (22). Coskun et al. found higher OPN concentrations in patients with acute coronary syndrome compared to patients with stable angina (48). Soe- 
jima et al. showed that OPN production in peripheral T cells is increased in relation to the severity of heart failure (49). OPN presumably plays an important role in the development of atherosclerosis $(25,50)$, acting in two different ways. First, OPN participates in the maintenance of chronic systemic inflammation through its cytokine and chemokine effects $(17,51)$. Second, Georgiadou et al. showed that in blood samples of patients with CAD, OPN concentrations are independently associated with MDA concentrations; a well-known biomarker of lipid peroxidation and oxidative stress (23). Systemic inflammation with an excessive Th1 response and oxidative stress also are essential factors in the pathogenesis of preeclampsia $(39,52)$. However, despite these facts, we could not establish any association between OPN concentrations and the markers of inflammation (CRP) or oxidative stress (MDA) in preeclampsia. It is possible that overproduction of OPN by activated peripheral blood mononuclear cells was masked by its rapid consumption during the exaggerated inflammatory processes in preeclampsia.

The extravillous trophoblasts of the human placenta also express OPN, which regulates the invasiveness of these cells (12). Gabinskaya et al. studied human placentas with immunostaining. They showed that after the 30th gestational week, OPN is only present in cytotrophoblasts of preeclamptic placentas, but not in healthy ones (53). It was previously reported that a significantly higher amount of trophoblast debris can be found in the maternal circulation in preeclampsia compared to women with a normal pregnancy $(41,42,54)$. Based on these observations, we examined the association between the concentrations of circulating fetal DNA as a marker of trophoblast debris, and OPN in maternal blood. However, we could not detect any relationship. Thus, we hypothesize that OPN can have only a local placental effect in preeclampsia.

Endothelial activation and injury play an important role in the pathogenesis of atherosclerosis, and OPN may participate in this process (13). Like atherosclerosis, preeclampsia is characterized by endothelial activation and injury. Therefore, we investigated whether plasma OPN concentrations are related to markers of endothelial activation (VWF:Ag), or endothelial damage (fibronectin) in preeclampsia. However, there was no relationship between VWF:Ag and OPN. Instead, we found a positive linear association between fibronectin and OPN concentrations. Furthermore, OPN concentrations were significantly higher in preeclamptic patients whose fibronectin concentrations were in the upper quartile compared to patients with preeclampsia with fibronectin below the 75th percentile, as well as to healthy pregnant women. In addition to having increased OPN concentrations, preeclamptic women with high fibronectin concentrations had a more severe form of the disease. OPN and fibronectin are components of the extracellular matrix and both contain an arginine-glycine-aspartic acid (RGD) sequence, which can bind integrin molecules. Interestingly, intermolecular crosslinking can be formed between these two proteins (55). Therefore, we suppose that OPN may be released from the vessel wall into the peripheral circulation together with fibro- nectin in cases of extensive endothelial injury. This might explain the observed association between plasma OPN and fibronectin concentrations in preeclampsia. However, the relationship of OPN to other markers of endothelial dysfunction or injury in preeclampsia, such as circulating endothelial cells (56), thrombomodulin (57), endothelin-1 and E-selectin (33) should be investigated in future studies to confirm our findings.

Preeclampsia is a heterogeneous syndrome with various clinical manifestations. We identified a subgroup of preeclamptic patients with significantly increased plasma OPN concentrations. Defining more homogeneous study populations in this way may help to understand the complex etiology and pathogenesis of this multifactorial disorder.

The limitations of our study are its case-control design and the relatively low number of patients involved. Also, we did not compare OPN production of peripheral blood mononuclear cells between cases and controls.

In conclusion, plasma OPN concentrations are increased in preeclamptic patients with extensive endothelial injury. However, further studies are warranted to explore the association of OPN with endothelial damage.

\section{Acknowledgements}

The skilful technical assistance of Szigeti Antalné and the support of Szilvia Walentin, Éva Imreh and Mónika Kleiber (Central Laboratory, Kútvölgyi Clinical Center, Semmelweis University, Budapest, Hungary) are acknowledged with many thanks.

\section{Conflict of interest statement}

Authors' conflict of interest disclosure: The authors stated that there are no conflicts of interest regarding the publication of this article. The funding sources played no role in the study design; in the collection, analysis, and interpretation of data; in the writing of the report; or in the decision to submit the report for publication.

Research funding: This work was supported by research grants from the Hungarian Scientific Research Fund (NF 72689) and the Faculty of Medicine of the Semmelweis University.

Employment or leadership: None declared.

Honorarium: None declared.

\section{References}

1. Duckitt K, Harrington D. Risk factors for pre-eclampsia at antenatal booking: systematic review of controlled studies. Br Med J 2005;330:565.

2. Redman CW, Sacks GP, Sargent IL. Preeclampsia: an excessive

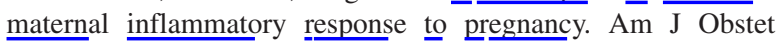
Gynecol 1999;180:499-506.

3. Saito S, Sakai M. Th1/Th2 balance in preeclampsia. J Reprod Immunol 2003;59:161-73.

4. Roberts JM, Gammill HS. Preeclampsia: recent insights. Hypertension 2005;46:1243-9.

5. Molvarec A, Jermendy A, Nagy B, Kovacs M, Varkonyi T, Hupuczi P, et al. Association between tumor necrosis factor 
(TNF)-alpha G-308A gene polymorphism and preeclampsia complicated by severe fetal growth restriction. Clin Chim Acta 2008;392:52-7.

6. Rosta K, Molvarec A, Enzsoly A, Nagy B, Ronai Z, Fekete A, et al. Association of extracellular superoxide dismutase (SOD3) Ala40Thr gene polymorphism with pre-eclampsia complicated by severe fetal growth restriction. Eur J Obstet Gynecol Reprod Biol 2009;142:134-8.

7. Nagy B, Varkonyi T, Molvarec A, Lazar L, Hupuczi P, Gabor Than N, et al. Leptin gene (TTTC)(n) microsatellite polymorphism in pre-eclampsia and HELLP syndrome. Clin Chem Lab Med 2009;47:1033-7.

8. Jaaskelainen E, Toivonen S, Keski-Nisula L, Paattiniemi EL, Helisalmi S, Punnonen K, et al. CTLA-4 polymorphism 49A$\mathrm{G}$ is associated with placental abruption and preeclampsia in Finnish women. Clin Chem Lab Med 2008;46:169-73.

9. Zhang J, Bai H, Liu X, Fan P, Liu R, Huang Y, et al. Genotype distribution of estrogen receptor alpha polymorphisms in pregnant women from healthy and preeclampsia populations and its relation to blood pressure levels. Clin Chem Lab Med 2009;47: 391-7.

10. Apparao KB, Murray MJ, Fritz MA, Meyer WR, Chambers AF, Truong PR, et al. Osteopontin and its receptor alphavbe$\mathrm{ta}(3)$ integrin are coexpressed in the human endometrium during the menstrual cycle but regulated differentially. J Clin Endocrinol Metab 2001;86:4991-5000.

11. Johnson GA, Burghardt RC, Joyce MM, Spencer TE, Bazer FW, Pfarrer C, et al. Osteopontin expression in uterine stroma indicates a decidualization-like differentiation during ovine pregnancy. Biol Reprod 2003;68:1951-8.

12. Briese J, Oberndorfer M, Patschenik C, Schulte HM, Makrigiannakis A, Loning T, et al. Osteopontin is colocalized with the adhesion molecule CEACAM1 in the extravillous trophoblast of the human placenta and enhances invasion of CEACAM1-expressing placental cells. J Clin Endocrinol Metab 2005;90:5407-13.

13. O'Brien ER, Garvin MR, Stewart DK, Hinohara T, Simpson JB, Schwartz SM, et al. Osteopontin is synthesized by macrophage, smooth muscle, and endothelial cells in primary and restenotic human coronary atherosclerotic plaques. Arterioscler Thromb 1994;14:1648-56.

14. Wang KX, Denhardt DT. Osteopontin: role in immune regulation and stress responses. Cytokine Growth Factor Rev $\overline{2008}$; $\overline{19: 333}-4 \overline{5}$.

15. Ashkar S, Weber GF, Panoutsakopoulou V, Sanchirico ME, Jansson M, Zawaideh S, et al. Eta-1 (osteopontin): an early component of type-1 (cell-mediated) immunity. Science 2000; 287:860-4.

16. Johnson GA, Burghardt RC, Bazer FW, Spencer TE. Osteopontin: roles in implantation and placentation. Biol Reprod 2003; $69: \overline{1458}-\overline{7} 1$.

17. Scatena M, Liaw L, Giachelli CM. Osteopontin: a multifunctional molecule regulating chronic inflammation and vascular disease. Arterioscler Thromb Vasc Biol 2007;27:2302-9.

18. Wong CK, Lit LC, Tam LS, Li EK, Lam CW. Elevation of plasma osteopontin concentration is correlated with disease activity in patients with systemic lupus erythematosus. Rheumatology (Oxford) 2005;44:602-6.

19. Comabella M, Pericot I, Goertsches R, Nos C, Castillo M, Blas Navarro J, et al. Plasma osteopontin levels in multiple sclerosis. J Neuroimmunol 2005;158:231-9.

20. Mishima R, Takeshima F, Sawai T, Ohba K, Ohnita K, Isomoto $\mathrm{H}$, et al. High plasma osteopontin levels in patients with inflammatory bowel disease. J Clin Gastroenterol 2007;41:167-72.
21. Mohler ER 3rd, Adam LP, McClelland P, Graham L, Hathaway DR. Detection of osteopontin in calcified human aortic valves. Arterioscler Thromb Vasc Biol 1997;17:547-52.

22. Ohmori R, Momiyama Y, Taniguchi H, Takahashi R, Kusuhara M, Nakamura H, et al. Plasma osteopontin levels are associated with the presence and extent of coronary artery disease. Atherosclerosis 2003;170:333-7.

23. Georgiadou P, Iliodromitis EK, Varounis C, Mavroidis M, Kolokathis F, Andreadou I, et al. Relationship between plasma osteopontin and oxidative stress in patients with coronary artery disease. Expert Opin Ther Targets 2008;12:917-20.

24. Kurata M, Okura T, Watanabe S, Fukuoka T, Higaki J. Osteopontin and carotid atherosclerosis in patients with essential hypertension. Clin Sci (Lond) 2006;111:319-24.

25. Giachelli CM, Bae N, Almeida M, Denhardt DT, Alpers CE, Schwartz SM. Osteopontin is elevated during neointima formation in rat arteries and is a novel component of human atherosclerotic plaques. J Clin Invest 1993;92:1686-96.

26. Roberts JM, Gammill H. Pre-eclampsia and cardiovascular disease in later life. Lancet 2005;366:961-2.

27. Paternoster DM, Fantinato S, Stella A, Nanhorngue KN, Milani $\mathrm{M}$, Plebani $\mathrm{M}$, et al. C-reactive protein in hypertensive disorders in pregnancy. Clin Appl Thromb Hemost 2006;12:330-7.

28. Molvarec A, Kalabay L, Derzsy Z, Szarka A, Halmos A, Stenczer B, et al. Preeclampsia is associated with decreased serum alpha(2)-HS glycoprotein (fetuin-A) concentration. Hypertens Res 2009;32:665-9.

29. Molvarec A, Rigo J Jr, Boze T, Derzsy Z, Cervenak L, Mako $\mathrm{V}$, et al. Increased plasma von Willebrand factor antigen levels but normal von Willebrand factor cleaving protease (ADAMTS13) activity in preeclampsia. Thromb Haemost 2009;101:305-11.

30. Stubbs TM, Lazarchick J, Horger EO 3rd. Plasma fibronectin levels in preeclampsia: a possible biochemical marker for vascular endothelial damage. Am J Obstet Gynecol 1984;150: 885-7.

31. Paternoster D, Stella A, Simioni P, Trovo S, Plebani P, Girolami A. Clotting inhibitors and fibronectin as potential markers in preeclampsia. Int J Gynaecol Obstet 1994;47:215-21.

32. Paternoster DM, Stella A, Simioni P, Girolami A, Plebani M. Fibronectin and antithrombin as markers of pre-eclampsia in pregnancy. Eur J Obstet Gynecol Reprod Biol 1996;70:33-9.

33. Aydin S, Benian A, Madazli R, Uludag S, Uzun H, Kaya S. Plasma malondialdehyde, superoxide dismutase, sE-selectin, fibronectin, endothelin-1 and nitric oxide levels in women with preeclampsia. Eur J Obstet Gynecol Reprod Biol 2004;113: $21-5$.

34. Ostlund E, Hansson LO, Bremme K. Fibronectin is a marker for organ involvement and may reflect the severity of preeclampsia. Hypertens Pregnancy 2001;20:79-87.

35. Paternoster DM, Stella A, Simioni P, Mussap M, Plebani M. Coagulation and plasma fibronectin parameters in HELLP syndrome. Int J Gynaecol Obstet 1995;50:263-8.

36. Leeflang MM, Cnossen JS, van der Post JA, Mol BW, Khan KS, ter Riet G. Accuracy of fibronectin tests for the prediction of pre-eclampsia: a systematic review. Eur J Obstet Gynecol Reprod Biol 2007;133:12-9.

37. Paternoster DM, Stella A, Mussap M, Plebani M, Gambaro G, Grella PV. Predictive markers of pre-eclampsia in hypertensive disorders of pregnancy. Int J Gynaecol Obstet 1999;66:237-43.

38. Uotila JT, Tuimala RJ, Aarnio TM, Pyykko KA, Ahotupa MO. Findings on lipid peroxidation and antioxidant function in 
hypertensive complications of pregnancy. Br J Obstet Gynaecol 1993;100:270-6.

39. Gupta S, Agarwal A, Sharma RK. The role of placental oxidative stress and lipid peroxidation in preeclampsia. Obstet Gynecol Surv 2005;60:807-16.

40. Padmini E, Lavanya S, Uthra V. Preeclamptic placental stress and over expression of mitochondrial $\underline{\mathrm{HSP} 70}$. Clin Chem Lab Med 2009;47:1073-80.

41. Zhong XY, Holzgreve W, Hahn S. The levels of circulatory cell free fetal DNA in maternal plasma are elevated prior to the onset of preeclampsia. Hypertens Pregnancy 2002;21:77-83.

42. Lo YM, Leung TN, Tein MS, Sargent IL, Zhang J, Lau TK, et al. Quantitative abnormalities of fetal DNA in maternal serum in preeclampsia. Clin Chem 1999;45:184-8.

43. Molvarec A, Rigo J Jr, Lazar L, Balogh K, Mako V, Cervenak $\mathrm{L}$, et al. Increased serum heat-shock protein 70 levels reflect systemic inflammation, oxidative stress and hepatocellular injury in preeclampsia. Cell Stress Chaperones 2009;14:151-9.

44. Molvarec A, Derzsy Z, Kocsis J, Boze T, Nagy B, Balogh K, et al. Circulating anti-heat-shock-protein antibodies in normal pregnancy and preeclampsia. Cell Stress Chaperones 2009;14: 491-8.

45. Joubert K. Standards of the body mass and body length of birth in Hungary on the basis of the 1990-1996 nation-wide liveborn data. Magy Noorv L 2000;63:155-63.

46. Placer ZA, Cushman LL, Johnson BC. Estimation of product of lipid peroxidation (malonyl dialdehyde) in biochemical systems. Anal Biochem 1966;16:359-64.

47. Lazar L, Nagy B, Ban Z, Nagy GR, Papp Z. Presence of cellfree fetal DNA in plasma of women with ectopic pregnancies. Clin Chem 2006;52:1599-601.

48. Coskun S, Atalar E, Ozturk E, Yavuz B, Ozer N, Goker H, et al. Plasma osteopontin levels are elevated in non-ST-segment elevation acute coronary syndromes. J Natl Med Assoc 2006; 98:1746-50.
49. Soejima H, Irie A, Fukunaga T, Oe Y, Kojima S, Kaikita K, et al. Osteopontin expression of circulating $\mathrm{T}$ cells and plasma osteopontin levels are increased in relation to severity of heart failure. Circ J 2007;71:1879-84.

50. Fitzpatrick LA, Severson A, Edwards WD, Ingram RT. Diffuse calcification in human coronary arteries. Association of osteopontin with atherosclerosis. J Clin Invest 1994;94:1597-604.

51. Cho HJ, Cho HJ, Kim HS. Osteopontin: a multifunctional protein at the crossroads of inflammation, atherosclerosis, and vascular calcification. Curr Atheroscler Rep 2009;11:206-13.

52. Saito S, Umekage H, Sakamoto Y, Sakai M, Tanebe K, Sasaki $\mathrm{Y}$, et al. Increased T-helper-1-type immunity and decreased Thelper-2-type immunity in patients with preeclampsia. Am J Reprod Immunol 1999;41:297-306.

53. Gabinskaya T, Salafia CM, Gulle VE, Holzman IR, Weintraub AS. Gestational age-dependent extravillous cytotrophoblast osteopontin immunolocalization differentiates between normal and preeclamptic pregnancies. Am J Reprod Immunol 1998;40: 339-46.

54. Schmidt M, Hoffmann B, Beelen D, Gellhaus A, Winterhager E, Kimmig R, et al. Detection of circulating trophoblast particles in peripheral maternal blood in preeclampsia complicated pregnancies. Hypertens Pregnancy 2008;27:131-42.

55. Beninati S, Senger DR, Cordella-Miele E, Mukherjee AB, Chackalaparampil I, Shanmugam V, et al. Osteopontin: its transglutaminase-catalyzed posttranslational modifications and cross-linking to fibronectin. J Biochem 1994;115:675-82.

56. Grundmann M, Woywodt A, Kirsch T, Hollwitz B, Oehler K, Erdbruegger U, et al. Circulating endothelial cells: a marker of vascular damage in patients with preeclampsia. Am J Obstet Gynecol 2008;198:317.e1-317.e5.

57. Nadar SK, Al Yemeni E, Blann AD, Lip GY. Thrombomodulin, von Willebrand factor and E-selectin as plasma markers of endothelial damage/dysfunction and activation in pregnancy induced hypertension. Thromb Res 2004;113:123-8. 